\title{
Application of response surface methodology for glucosyltransferase production and conversion of sucrose into isomaltulose using free Erwinia sp. cells
}

\author{
Haroldo Yukio Kawaguti* \\ Laboratory of Food Biochemistry \\ Department of Food Science \\ Faculty of Food Engineering \\ State University of Campinas (UNICAMP) \\ Rua Monteiro Lobato 80 \\ CEP 13083-862, C.P.6121 \\ Campinas, Brazil \\ Tel: 551937882175 \\ Fax: 551937882153 \\ E-mail: kawaguti@fea.unicamp.br \\ Eiric Manrich \\ Biocen do Brasil \\ Rua Pedro Stancato, 690 \\ Chácara Campos dos Amarais \\ CEP 13082-050 \\ Campinas, Brazil \\ Tel: 551932461697 \\ Fax: 551932462581 \\ E-mail: eiric@biocendobrasil.com.br \\ Hélia Harumi Sato \\ Laboratory of Food Biochemistry \\ Department of Food Science \\ Faculty of Food Engineering \\ State University of Campinas (UNICAMP) \\ Rua Monteiro Lobato 80 \\ CEP 13083-862, C.P.6121 \\ Campinas, Brazil \\ Tel: 551935212175 \\ Fax: 551935212153 \\ E-mail: heliah@fea.unicamp.br
}

Financial support: Coordenação de Aperfeiçoamento de Pessoal de Nível Superior (CAPES), Financiadora de Estudos e Projetos em Pesquisa (FINEP) and GETEC Guanabara Química Industrial S.A.

Keywords: batch process, Erwinia sp., free cells, glucosyltransferase, isomaltulose, response surface methodology.
Abbreviations: $\quad 2^{3}$-FCCD: $2^{3}$-factorial central composite designs SCM: sugar cane molasses BP: bacteriological peptone YEP: yeast extract Prodex Lac SD ${ }^{\circledR}$

Isomaltulose is a structural isomer of sucrose commercially used in food industries. Glucosyltransferase produced by Erwinia sp. D12 catalyses an intramolecular transglucosylation of sucrose giving isomaltulose. The Experimental design and response surface methodology were applied for the optimization of the nutrient concentration in the culture medium for the enzyme production in shaken flasks at
$200 \mathrm{rpm}$ and $30^{\circ} \mathrm{C}$. The three variables involved in this study were sugar cane molasses, bacteriological peptone and yeast extract Prodex Lac SD ${ }^{\circledR}$. The statistical analysis of the results showed that, in the range studied, all the factors had a significant effect $(p<0.05)$ on glucosyltransferase production and the highest enzyme activity was observed in culture medium containing sugar cane molasses $(160 \mathrm{~g} / \mathrm{L})$, bacteriological peptone

*Corresponding author 
$(20 \mathrm{~g} / \mathrm{L})$ and yeast extract Prodex Lac $\mathrm{SD}^{\circledR}(15 \mathrm{~g} / \mathrm{L})$. Maximum glucosyltransferase activity of $29.88 \mathrm{U} / \mathrm{mL}$ was achieved in a 6.6- $\mathrm{L}$ fermenter using the optimized medium. Free Erwinia sp. D12 cells were used for isomaltulose production from sucrose during fifteen successive batches. The final isomaltulose concentration of $75.6 \%$ obtained in the first batch increased to $77.21 \%$ (mean value) in the other fourteen batches and the productivity of $1.1 \mathrm{~g} / \mathrm{L} \mathrm{x}$ hr was obtained in batch process.

The enzyme glucosyltransferase is an industrially important enzyme since it produces non-cariogenic isomaltulose (6O- $\alpha$-D-glucopyronosyl-1-6-D-fructofuranose) from sucrose by an intramolecular transglucosylation (Kakinuma et al. 1998). Isomaltulose is a reducing sugar and it is a structural isomer of sucrose naturally presents in honey in very small quantities. The interest in isomaltulose is due to the low cariogenic, low hydrolysis speed and formation of monosaccharides in the organism, and also due to the possibility of conversion of this sugar to a mixture of sugaralcohol with low caloric value and non-cariogenic property known as Isomalt ${ }^{\circledR}$ or Palatinit ${ }^{\circledR}$. This disaccharide has a sweet taste and very similar physical and organoleptic properties to sucrose (Krastanov and Yoshida, 2003).

Chemical synthesis of isomaltulose is very difficult but a small number of bacterial strains can convert sucrose into isomaltulose: Protaminobacter rubrum (Kakinuma et al. 1998), Erwinia rhapontici (Cheetham et al. 1985), Serratia plymuthica (McAllister et al. 1990), Klebsiella planticola (Huang et al. 1998), Klebsiella sp. (Park et al. 1996) and Klebsiella singaporensis sp. (Li et al. 2004). The microbial formation of isomaltulose has attracted commercial interest and the production of this sugar has aroused great interest since this structural isomer of sucrose has interesting potential.

The application of experimental design and response surface methodology in fermentations process can result in improved product yields, reduced process variability and development time and over all costs (Rao et al. 2000). In this work, the effect of both nitrogen source (bacteriological peptone and yeast extract) and carbon source concentrations (sugar cane molasses) on glucosyltransferase production by Erwinia sp. D12 was studied at $30^{\circ} \mathrm{C}$ and the optimal conditions for glucosyltransferase production were determined in shaken flasks and on a bioreactor 6.6 litres. The conversion of sucrose into isomaltulose by immobilized cells well knows process (Cheetham et al. 1982; Cheetham et al. 1985; Ahn et al. 2003; Krastanov and Yoshida, 2003; Zhao et al. 2003; Moraes et al. 2005). An attempt was made to study the production of isomaltulose in repeated batch operations using free Erwinia sp. D12 cells.

\section{MATERIALS AND METHODS}

\section{Microorganism and culture maintenance}

Erwinia sp. D12 producer of glucosyltransferase isolated from the Laboratory of Biochemistry, Department of Food Science, College of Food Engineering/UNICAMP was used in this study. Bacteria were maintained in culture medium containing per litre sterilized water: $6 \mathrm{~g}$ sucrose, $4 \mathrm{~g}$ peptone, $0.4 \mathrm{~g}$ beef extract and $2 \mathrm{~g}$ agar. The cultures were kept at $5^{\circ} \mathrm{C}$ and renewed every 8 weeks.

\section{Culture medium optimization using response surface methodology}

Three $2^{3}$-factorial central composite designs $\left(2^{3}\right.$-FCCD $)$ were carried out in order to identify optimum parameter levels for the glucosyltransferase production. The parameters (or independent variables) studied were: sugar cane molasses (Companhia Energética Santa Elisa), bacteriological peptone (Biobrás) and yeast extract Prodex Lac SD ${ }^{\circledR}$ (Prodesa produtos especiais para alimentos S.A.). The dependent variables and their levels are presented in Table 1 (first $2^{3}$-FCCD), Table 2 (second $2^{3}$-FCCD) and Table 3 (third $2^{3}$-FCCD). The FCCD contained a total of 17 experimental trials that included eight trials for factorial points, six trials for axial points and three trials for replication of the central points. Central points provide additional degrees of freedom for error estimating, which increases power when testing the significance of effects. The distance of the axial points was \pm 1.68 , calculated from Equation 1:

$$
\alpha=\left(2^{\mathrm{n}}\right)^{1 / 4}[1]
$$

where $\alpha$ is the distance of the axial points and $n$ is the number of independent variables. All data were treated with STATISTICA $^{\circledR} 5.0$ from Statsoft Inc.

\section{Cultivation and enzyme production}

The inoculum had the same composition of the production medium which they are shown in Table 1, Table 2 and Table 3. A loop full of cells was inoculated to inoculum in Erlenmeyer flasks of $250 \mathrm{~mL}$ containing $50 \mathrm{~mL}$ of culture medium and the flasks were incubated in a rotatory shaker (200 rpm) at $30^{\circ} \mathrm{C}$ for $15 \mathrm{hrs}$. Then a $10 \%$ (v/v) inoculum was added to production medium. Throughout the work, liquid cultures were incubated at $30^{\circ} \mathrm{C}$ and $200 \mathrm{rpm}$ in a rotatory shaker (New Brunswick Scientific, Edison, N.J., USA). After $8 \mathrm{hrs}$ of fermentation, the culture was centrifuged (Centrifuge Beckman J2-21, Beckman-Coulter, Inc., Fullerton, CA, USA) at $9,650 \mathrm{x}$ g for $15 \mathrm{~min}$ and glucosyltranferase activity was determined.

\section{Glucosyltransferase assay}

The glucosyltransferase activity was performed by the increase of the reducing power from a solution containing sucrose, described by Park et al. (1996) with modifications. 
For the extraction of intracellular enzyme, the cell mass was washed twice with distilled water and then suspended in $50 \mathrm{~mL}$ citrate-phosphate buffer $0.05 \mathrm{M} \mathrm{pH}$ 6.0. The cell suspension was cooled to $5^{\circ} \mathrm{C}$ and disrupted by ultrasonic oscillation $180 \mathrm{~W}$ for $20 \mathrm{sec}$ (Labline Instruments, Inc., Illinois, USA). After cell wall disruption, the samples were centrifuged at $7,850 \mathrm{xg}$ for $15 \mathrm{~min}$ at $5^{\circ} \mathrm{C}$. The enzyme activity of the supernatant was determined. A mixture of $450 \mu \mathrm{L}$ of a $4 \%(\mathrm{w} / \mathrm{v})$ sucrose solution in $0.05 \mathrm{M}$ citratephosphate buffer $\mathrm{pH} 6.0$ and $50 \mu \mathrm{L}$ of enzyme solution was incubated for $20 \mathrm{~min}$ at $35^{\circ} \mathrm{C}$. Reducing sugars were measured by Somogyi method (Somogyi, 1945) using glucose as standard. One activity unit (U) of glucosyltransferase is defined as the amount of enzyme that liberates one $\mu \mathrm{mol}$ of reducing sugars $/ \mathrm{minute} / \mathrm{mL}$ of the enzyme from sucrose under standard assay conditions.

\section{Production of cell biomass: growth determination and glucosyltransferase production under optimal culture medium in 6.6-L fermenter}

Bacterial growth and glucosyltransferase activity were determined under optimal culture medium: sugar cane molasses $(160 \mathrm{~g} / \mathrm{L})$, bacteriological peptone $(20 \mathrm{~g} / \mathrm{L})$ and yeast extract Prodex Lac SD (15 g/L) on a bioreactor 6.6-L fermenter New Brunswick Bioflo IIc (New Brunswick Scientific, Edison, N.J., USA). Two loop full of culture were inoculated in three $250 \mathrm{~mL}$ Erlenmeyer flasks containing $100 \mathrm{~mL}$ of culture medium optimized each one and incubated in a rotatory shaker $200 \mathrm{rpm}$ at $30^{\circ} \mathrm{C}$ for 15 hrs. An aliquot of $300 \mathrm{~mL}$ inoculum was transferred to $2.700 \mathrm{~mL}$ of culture medium optimized contained in a 6.6$\mathrm{L}$ fermenter and incubated under the following conditions: temperature $26^{\circ} \mathrm{C}$, initial $\mathrm{pH} 6.5$, aeration rate $1 \mathrm{vvm}$, and agitation speed $200 \mathrm{rpm}$. Samples were collected at timedefined intervals and submitted to analysis. Aliquots (20 $\mathrm{mL}$ ) of the culture broth were centrifuged at 7,850 x $\mathrm{g}$ for $15 \mathrm{~min}$, at $5^{\circ} \mathrm{C}$. The cell mass was washed twice with 20 $\mathrm{mL}$ of distilled water and re-suspended in $20 \mathrm{~mL}$ of distilled water. A Beckman DU 70 spectrophotometer (Beckman-Coulter, Inc., Fullerton, CA, USA) was used to monitor cell growth by measuring the optical density at 660 $\mathrm{nm}\left(\mathrm{OD}_{660}\right)$. Glucosyltransferase activity was estimated as described previously. The $\mathrm{pH}$ of the culture medium was measured with an Orion model 710A potentiometer (Orion Research Inc, Boston, MA, USA).

\section{Performance of repeated batch operations using free cells}

Duplicate repeated batch conversion runs were carried out in $250 \mathrm{~mL}$ Erlenmeyer flaks containing the mixture of $35 \%$ $(\mathrm{w} / \mathrm{v})$ sucrose solution and free-cell of Erwinia sp. D12 (sucrose solution:free-cell - 10:1). The flasks were maintained in a rotatory shaker at $150 \mathrm{rpm}$ and $35^{\circ} \mathrm{C}$ for 15 min. At the end of each batch, samples were collected and submitted to analysis, the reaction mixture was centrifuged and the free-cells were used for the next batch conversion of sucrose into isomaltulose with the fresh substrate. This process was repeated for several times.

\section{Viable cell numbers, biomass, pH and HPLC-PAD analysis}

Samples were submitted to serial dilutions and viable counts were performed by spread plate technique. The biomass (wet cell mass) was measured with a precision balance (Satorius AG, Goettingen, GE). The $\mathrm{pH}$ of the culture medium was measured with an Orion model 710A potentiometer (Orion Research Inc, Boston, MA, USA). The sugars analysis was performed with HPLC system consisted of a DIONEX DX-600 chromatograph equipped with a Electrochemical Detector ED50, a CarboPac ${ }^{\mathrm{TM}}$ PA 1 column $(4 \mathrm{~mm} \times 270 \mathrm{~mm})$, and a CarboPac ${ }^{\mathrm{TM}} \mathrm{PA} 1$ guard column (4 mm x $500 \mathrm{~mm})$, with a mobile phase of $200 \mathrm{mM}$ $\mathrm{NaOH}$ solution and a flow rate of $1 \mathrm{~mL} / \mathrm{min}$ at $20^{\circ} \mathrm{C}$. The carbohydrates were analyzed from their retention times as compared to those of the fructose, glucose, sucrose and isomaltulose standards (Sigma Chemical Co., St. Louis, MO, USA).

\section{RESULTS AND DISCUSSION}

\section{Culture medium optimization using response surface methodology}

First experimental design. The experimental results of glucosyltransferase production by the first $2^{3}$-FCCD are shown in Table 1. The effect estimates for each variable: sugar cane molasses (SCM), bacteriological peptone (BP) and yeast extract Prodex Lac SD ${ }^{\circledR}$ (YEP), as well as the interaction between them, were determined and reported in Table 4 . Both the t-test and $p$-value statistical parameters are used to confirm the significance of factors studied. All the independent variables had significant influence in glucosyltransferase activity $(\mathrm{p}<0.05)$, as well as the interactions between them. The increase in BP concentration from 10 to $50 \mathrm{~g} / \mathrm{L}$ led to an increase in enzyme activity.

The parameter SCM (L) showed higher effect than SCM (Q) indicating that the increase the concentration from 100 to $250 \mathrm{~g} / \mathrm{L}$ led to a decreased in glucosyltransferase production. The independent variable ELP showed the same effect. A model fitting was accomplished for the first $2^{3}$-FCCD in Table 1 . The independent (glucosyltransferase activity) and the dependent variables were fitted to the second-order model equation and examined in terms of the goodness of fit. The analysis of variance (ANOVA) was used to evaluate the adequacy of the fitted model. The Rsquare value (determination coefficient) provided a measure of how much of the variability in the observed response values could be explained by the experiment factors and their interactions.

On the basis of ANOVA, as shown in Table 5, a secondorder model was established (Equation 2) describing the 
enzyme activity as a function of SCM, BP and YEP concentrations. The pure error was very low (0.002) indicating a good reproducibility of the experimental data. Based on the $F$-test, the model is predictive, since its calculated $F$-value is higher than the critical F-value. The coded model was used to generate response surfaces and contour curves for the analysis of the variable effects on glucosyltransferase activity:

$y=0.39-0.95 x_{1}+0.52 x_{1}^{2}+0.24 x_{2}+0.34 x_{2}^{2}-0.68 x_{3}$

$-0.27 x_{3}+0.24 x_{1} \cdot x_{2}+1.59 x_{1} \cdot x_{3}+0.14 x_{2} \cdot x_{3}$

where $y$ is the predicted response (glucosyltransferase activity) and $x_{1}, x_{2}$ and $x_{3}$ are the coded values of sugar cane molasses, bacteriological peptone and yeast extract Prodex Lac SD ${ }^{\circledR}$, respectively. As can be seen in Figure 1 and Figure 2 an increase in sugar cane molasses and yeast extract Prodex Lac SD ${ }^{\circledR}$ concentrations led to an decrease in enzyme activity. In the second experimental design, the concentration ranges of SCM, BP and YEP were decreased.

Second experimental design. The trials and results for the second $2^{3}$-FCCD are shown in Table 2 . The effect estimates were determined and reported in Table 4. The analysis of the effects shows that an increase in the concentration of bacteriological peptone from 5 to $35 \mathrm{~g} / \mathrm{L}$ and concentration of yeast extract from 10 to $50 \mathrm{~g} / \mathrm{L}$ led to a decrease in glucosyltransferase activity. All interactions between SCM, BP and YEP were statistically significant for enzyme activity. To test the fit of the model the regression equation and determination coefficient (R-square) were calculated. The model presented high determination coefficient (Rsquare $=0.90$ ) explaining $90 \%$ of the variability in the response (Table 6). The ANOVA of quadratic regression model demonstrates that the model is highly significant, as is evident from the F-test.

Based on these results the model can be utilized to generate response surfaces and contour curves for the analysis of the variable effects on glucosyltransferase activity. The response surface and contour curves were obtained using Equation 3:

$y=8.13+0.56 x_{1}-0.64 x_{1}^{2}-0.19 x_{2}^{2}-0.33 x_{3}-$

$0.27 x_{1} \cdot x_{2}-0.30 x_{1} \cdot x_{3}-0.63 x_{2} \cdot x_{3}$

It can be seen that an decrease in YEP led to an increase in enzyme activity and the best concentrations for SCM and BP were 135 to $190 \mathrm{~g} / \mathrm{L}$ and 5 to $30 \mathrm{~g} / \mathrm{L}$, respectively.

Third experimental design. The trials and results for the third $2^{3}$-FCCD are shown in Table 3. According to the results obtained, the best conditions for glucosyltransferase production occurred in experiments 15, 16 and 17 corresponding to the central points. These experiments correspond to the cultivation medium composed by sugar cane molasses $160 \mathrm{~g} / \mathrm{L}$, bacteriological peptone $20 \mathrm{~g} / \mathrm{L}$ and yeast extract Prodex Lac SD $15 \mathrm{~g} / \mathrm{L}$.
On the basis of the ANOVA, shown in Table 6, a secondorder model (Equation 4) was established, describing the enzyme activity as a function of SCM, BP and YEP concentrations:

$y=7.28-1.05 x_{1}-2.38 x_{1}^{2}-1.56 x_{2}^{2}-1.69 x_{3}^{2}-$

$0.68 x_{1} \cdot x_{2}$

Based on the F-test the model is predictive, since the $F$ value calculated is 8.75 higher than the critical $F$-value and the determination coefficient 0.94 is close to unity. The pure error was very low, indicating a good reproducibility of the experimental data. The response surfaces and contour curves in Figure 5 and Figure 6 were obtained using Equation 4. It can be see that the maximum glucosyltransferase activity point is situated close to the central point.

The model predicted the maximum activity in culture medium composed by SCM (160 g/L), BP (20 g/L) and YEP $(15 \mathrm{~g} / \mathrm{L})$ in the conditions studied. It was obtained $7.26 \mathrm{U} / \mathrm{mL}$ (average of the central points) after $8 \mathrm{hrs}$ fermentation at $30^{\circ} \mathrm{C}$.

\section{Production of cell biomass: growth determination and glucosyltransferase production under optimal culture medium in 6.6-L fermenter}

After optimization, fermentation kinetics was determined at the optimized conditions, as observed in Figure 7. Glucosyltransferase production and growth characteristics of Erwinia sp. D12 using culture medium optimized are illustrated. The glucosyltransferase production started at exponential growth phase and the enzyme activity was increased at the beginning of the cultivation ( 2 hrs of fermentation time) and reached a maximum level. Subsequently, the glucosyltransferase activity decreased slowly after $9 \mathrm{hrs}$ of fermentation time. The highest enzyme activity was obtained after $9 \mathrm{hrs}(29.88 \mathrm{U} / \mathrm{mL})$ after inoculum and the activity was maintained constant, between 23-25 U/mL, until $14 \mathrm{hrs}$ of fermentation time. Thereafter, the glucosyltransferase production was diminished and after $24 \mathrm{hrs}$ de enzyme activity decreased to $16.06 \mathrm{U} / \mathrm{mL}$. The $\mathrm{pH}$ of the culture medium was about $6.5-$ 6.5 during fermentation, suggesting little production of acid as a by-product.

The activity value of $29.88 \mathrm{U} / \mathrm{mL}$ obtained from Erwinia $\mathrm{sp}$ D12 cells is approximately ten times higher than the one produced by Park et al. (1996) using strain Klebsiella sp. in a culture medium composed by $1 \%$ bacteriological peptone, $0.4 \%$ beef extract powder and $4 \%$ sucrose when they obtained $2.95 \mathrm{U} / \mathrm{mL}$. Huang et al. (1998) examined the effects of carbon sources, inorganic salt and supplemental nitrogen sources on intracellular glucosyltransferase activity of Klebsiella planticola CCRC 19112. It was obtained a maximum glucosyltransferase activity of 11.08 $\mathrm{U} / \mathrm{mL}$ using a culture medium composed by $1 \%$ bactotryptone, $7 \%$ sucrose, $3 \%$ tryptic soy broth and $0.5 \% \mathrm{NaCl}$. 
Li et al. (2004) using the strain Klebsiella sp. LX3 cultured aerobically in the culture medium composed by $4 \%$ sucrose, $1 \%$ bacteriological peptone and $0.4 \%$ yeast extract. The authors determined the glucosyltransferase activity in cell culture, supernatant, cell-free extract and cell-debris fractions. The enzyme activity of the cell-debris fraction $(19.2 \mathrm{U} / \mathrm{mL})$ was almost identical to that of cell culture fraction $(20.1 \mathrm{U} / \mathrm{mL})$. This result suggesting that the glucosyltransferase is a cell wall bound enzyme. Moraes et al. (2005) obtained $15.6 \mathrm{U} / \mathrm{mL}$ of glucosyltranferase activity from Erwinia sp. cells incubated in 3.0-L fermenter containing culture medium composed by $12 \%$ sugar cane molasses, $4 \%$ bacteriological peptone and $0,4 \%$ beef extract, at $30^{\circ} \mathrm{C} 200 \mathrm{rpm}$ and $1 \mathrm{vvm}$. Overall, in this work, sugar cane molasses (agro-industrial residue) and commercial yeast extract were used with the purpose of resulting in a low cost culture media. The cell mass obtained from the bioreactor fermentation was used in further studies to verify the conversion of sucrose into isomaltulose from free-cells.

\section{Performance of repeated batch operations using free cells}

The data obtained for 15 cycles of repeated batch operation shown in Table 8 and Figure 8 indicated that free cells were active and could be reused. The biomass (wet cell mass) decreased with the batches of operation for the first five cycles of operation and remained almost steady for the subsequent batches between $3.73 \mathrm{~g}$ and $3.33 \mathrm{~g}$ of wet cell mass. The $\mathrm{pH}$ of the medium reaction remained constantly between 6.0-6.5, however after seventy batches the $\mathrm{pH}$ decrease to 5.5 remained in this value suggesting little production of acid as a by-product. It can be observe that the growth as free cells did occur slowly (viable cell number) in the reaction medium between the first and the fifteenth batches. After eight batches the viable cell number diminished gradually. The wet cell mass and the viable cell number decreased but did not affect the conversion of sucrose into isomaltulose. Table 8 and Figure 8 show the high conversion of sucrose into isomaltulose between 73$79 \%$. As can be verified the efficiency of production of isomaltulose increased after the first batch, leading to increases in the isomaltulose concentration and productivities (around $1.1 \mathrm{~g} / \mathrm{L} \mathrm{x} \mathrm{h}$ ) in the last batches. The highest conversion of sucrose into isomaltulose was $79.2 \%$ (batch number eight). The isomaltulose production using free Erwinia sp. cells was very efficient. It was obtained high yield from 35\% sucrose solution with high speed about fifty minutes reaction time for complete conversion. Tsuyuki et al. (1992) obtained 63.9\% isomaltulose using cells of Klebsiella planticola MX-10 incubated with $20 \%$ sucrose solution in $0.04 \mathrm{M}$ calcium acetate buffer $\mathrm{pH} 5.6$ at $20^{\circ} \mathrm{C}$ for $1 \mathrm{~h}$ incubation time. When $1 \mathrm{~mL}$ Klebsiella planticola CCRC 19221 cell suspension was incubated with $5 \mathrm{~mL}$ of a $50 \%$ sucrose solution at $40^{\circ} \mathrm{C}$ for $24 \mathrm{hrs}$ incubation time with agitation it was obtained $76 \%$ of isomaltulose (Huang et al. 1998). Harvested cells of Pantoeae dispersa UQ68J, Protaminobacter rubrum
CBS574.77 and Erwinia rhapontici WAC2928 (Wu and Birch, 2004) were resuspended in $0.2 \mathrm{~mL}$ citrate-fosfate buffer $0.1 \mathrm{~mol} / \mathrm{L}$ and they were incubated with $0.2 \mathrm{~mL}$ of the same buffer containing 50\% sucrose solution. After 20 min incubation time, the cell suspension of Pantoeae dispersa UQ68J yielded $79 \%$ isomaltulose. In the same incubation time, Protaminobacter rubrum CBS574.77 accomplished 50\% conversion, and Erwinia rhapontici WAC2928 accomplished only $2 \%$ conversion.

\section{CONCLUDING REMARKS}

With the aid of the experimental design and response surface methodology, the optimal concentrations of sugar cane molasses, bacteriological peptone and yeast extract Prodex Lac SD ${ }^{\circledR}$ for the production of glucosyltransferase by Erwinia sp. D12 were found to be $160 \mathrm{~g} / \mathrm{L}, 20 \mathrm{~g} / \mathrm{L}$ and $15 \mathrm{~g} / \mathrm{L}$, respectively. The highest glucosyltransferase activity was obtained at $30^{\circ} \mathrm{C}$ after 8 hrs of fermentation time. The results were satisfactory and the components sugar cane molasses and yeast extract Prodex Lac SD ${ }^{\circledR}$ are very useful carbon and nitrogen sources, respectively to enzyme production. Maximum glucosyltransferase activity of $29.88 \mathrm{U} / \mathrm{mL}$ was achieved in a 6.6-1 fermenter using the optimized medium at $26^{\circ} \mathrm{C}, 200 \mathrm{rpm}$ agitation, and $1 \mathrm{vvm}$ aeration rate. The free Erwinia sp. D12 cells supported high production levels in repeated batch operations and the results showed potential for repeated reuse of free-cells.

\section{ACKNOWLEDGMENTS}

We thank the Prodesa Produtos Especiais para Alimentos S/A for the supply of the yeast extract Prodex Lac SD ${ }^{\circledR}$.

\section{REFERENCES}

AHN, Seung-Joon; YOO, Ji-Hyun; LEE, Hyeon-Cheol; KIM, Sang-Yong; NOH, Bong-Soo; KIM, Jung-Hoe and LEE, Jung-kul. Enhanced conversion of sucrose to isomaltulose by a mutant of Erwinia rhapontici. Biotechnology Letters, July 2003, vol. 25, no. 14, p. 11791183.

CHEETHAM, Peter S.J.; IMBER, Carol E. and ISHERWOOD, Jamie. The formation of isomaltulose by immobilized Erwinia rhapontici. Nature, October 1982, vol. 299 , no. 5884 , p. $628-631$.

CHEETHAM, Peter S.J.; GARRETT, Christine and CLARK, Jeremy. Isomaltulose production using immobilized cells. Biotechnology and Bioengineering, April 1985, vol. 27, no. 4, p. 471-481.

HUANG, J.-H.; HSU, L.-H. and SU, Y.-C. Conversion of sucrose to isomaltulose by Klebsiella planticola CCRC 19112. Journal of Industrial Microbiology and Biotechnology, August 1998, vol. 21, no. 1-2, p. 22-27.

KAKINUMA, Hiroyuki; YUASA, Hideya and HASHIMOTO, Hironobu. Glycosyltransfer mechanism of 


\section{Kawaguti, H.Y. et al.}

a-glucosyltransferase from Protaminobacter rubrum. Carbohydrate Research, November 1998, vol. 312, no. 3, p. 103-115.

KRASTANOV, Albert and YOSHIDA, Toshiomi. Production of palatinose using Serratia plymuthica cells immobilized in chitosan. Journal of Industrial Microbiology and Biotechnology, October 2003, vol. 30, no. 10, p. $593-598$.

LI, Xianzhen; ZHANG, Daohai; CHEN, Feng; MA, Jie; DONG, Yihu and ZHANG, Lianhui. Klebsiella singaporensis sp. nov., a novel isomaltulose-producing bacterium. International Journal of Systematic and Evolutionary Microbiology, November 2004, vol. 54, no. 6, p. 2131-2136.

MCALLISTER, M.; KELLY, C.T.; DOYLE, E. and FOGARTY, W.M. The isomaltulose synthesing enzyme of Serratia plymuthica. Biotechnology Letters, September 1990, vol. 12, no. 9, p. 667-672.

MORAES, Ana Lúcia Leite; STECKELBERG, Claúdia; SATO, Hélia Harumi and PINHEIRO, Andrelina. Produção de isomaltulose a partir da transformação enzimática da sacarose, utilizando-se Erwiniasp D12 imobilizada com alginato de cálcio. Ciência e Tecnologia de Alimentos, January-March 2005, vol. 25, no. 1, p. 95-102.

PARK, Y.K.; UEKANE, R.T. and SATO, H.H. Biochemical characterization of a microbial glucosyltransferase that converts sucrose to patatinose. Revista de Microbiologia, April-June 1996, vol. 27, p. 131136.

RAO, K. Jagannadha; KIM, Chul-Ho and RHEE, Sang-Ki. Statistical optimization of medium for the production of recombinant hirudin from Saccharomyces cerevisiae using response surface methodology. Process Biochemistry, February 2000, vol. 35, no. 7, p. 639-647.

SOMOGYI, Michael. A new reagent for the determination of sugars. Journal of Biological Chemistry, September 1945, vol. 160, no. 1, p. 61-68.

TSUYUKI, K.; SUGITANI, T.; MIYATA, Y.; EBASHI, T. and NAKAJIMA, Y. Isolation and characterization of Isomaltulose-and trehalulose-producing bacteria from Thailand soil. Journal of General and Applied Microbiology, October 1992, vol. 38, no. 5, p. 483-490.

WU, L. and BIRCH, R.G. Characterization of Pantoeae dispersa UQ68J: producer of a highly efficient sucrose isomerase for isomaltulose biosynthesis. Journal of Applied Microbiology, July 2004, vol. 97, no. 1, p. 93-103.

ZHAO, C.; ZHANG, D. and LI, X. Substrate induction of isomaltulose synthase in a newly isolated Klebsiella sp. LX3. Journal of Applied Microbiology, September 2003, vol. 95 , no. 3, p. 521-527. 


\section{APPENDIX}

\section{FIGURES}
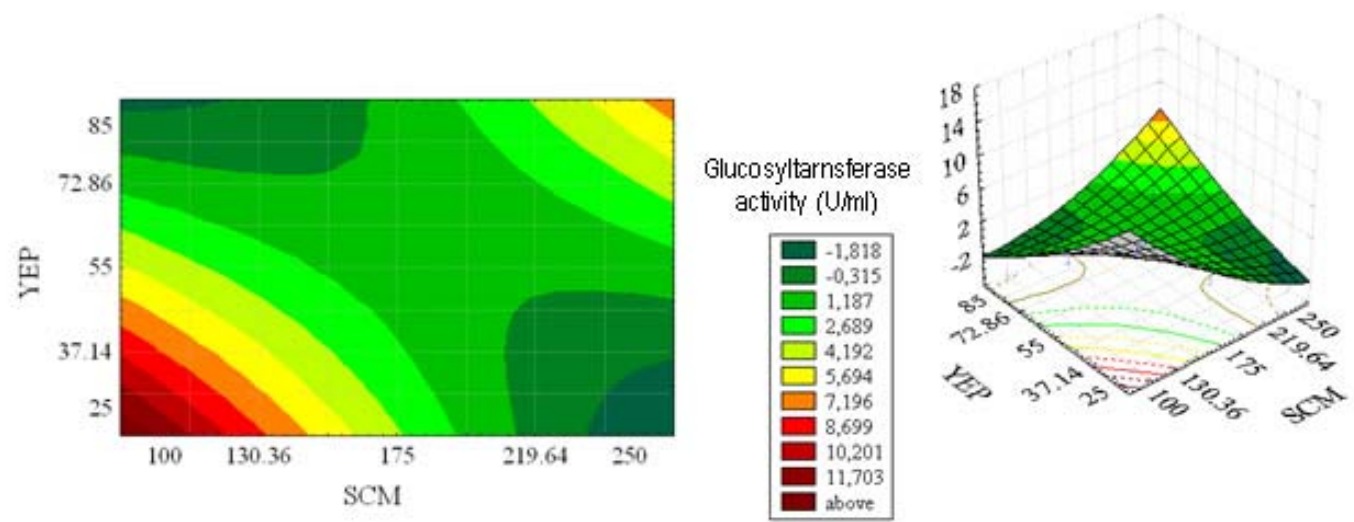

Figure 1. Contour curve and response surface for the glucosyltransferase activity as a function of sugar cane molasses (SCM) and veast extract Prodex Lac SD (YEP) concentrations. accordina to the first experimental desian.
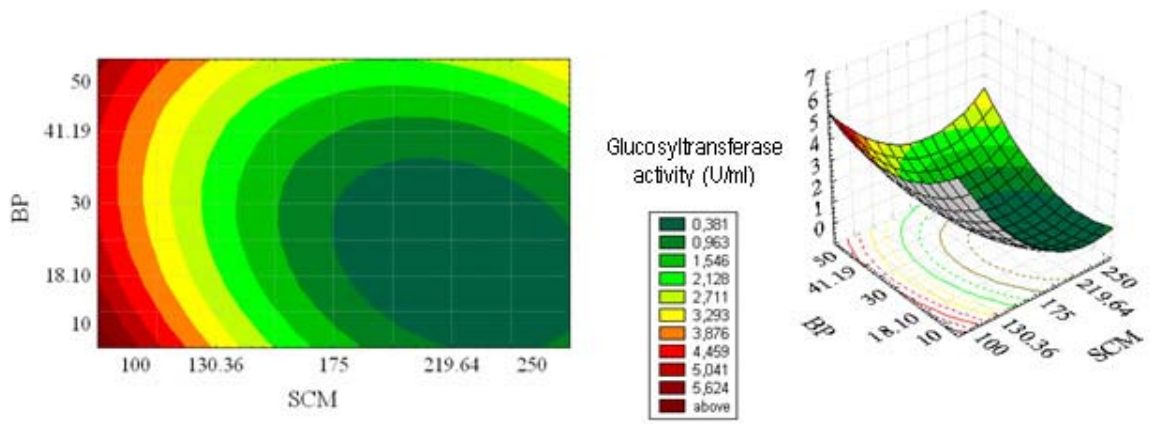

Figure 2. Contour curve and response surface for the glucosyltransferase activity as a function of sugar cane molasses (SCM) and bacteriological peptone (BP) concentrations, according to the first experimental design.
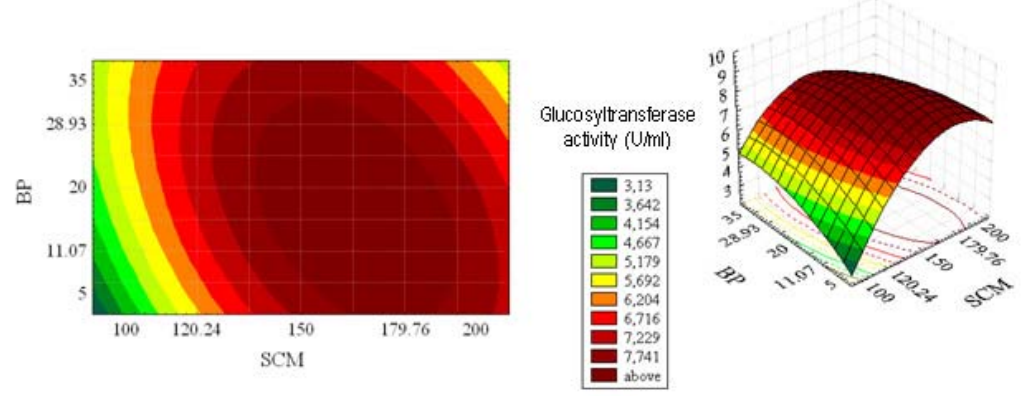

Figure 3. Contour curve and response surface for the glucosyltransferase activity as a function of sugar cane molasses (SCM) and bacterioloaical peptone (BP) concentrations. according to the second experimental desian. 

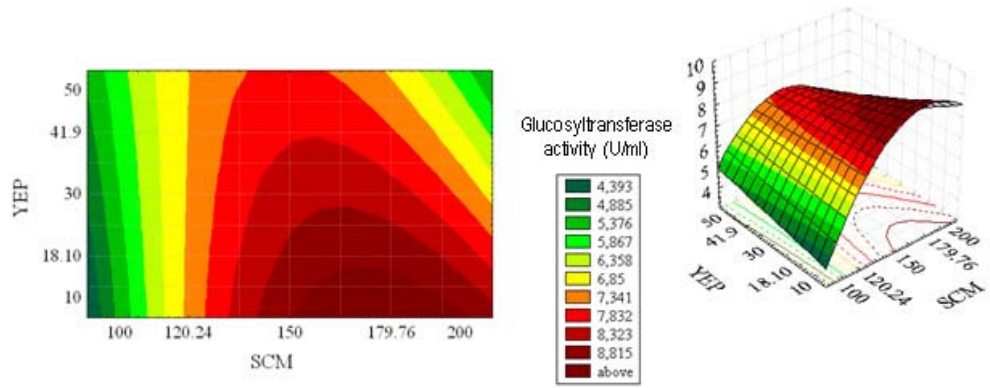

Figure 4. Contour curve and response surface for the glucosyltransferase activity as a function of sugar cane molasses (SCM) and yeast extract Prodex Lac SD (YEP) concentrations, according to the second experimental design.
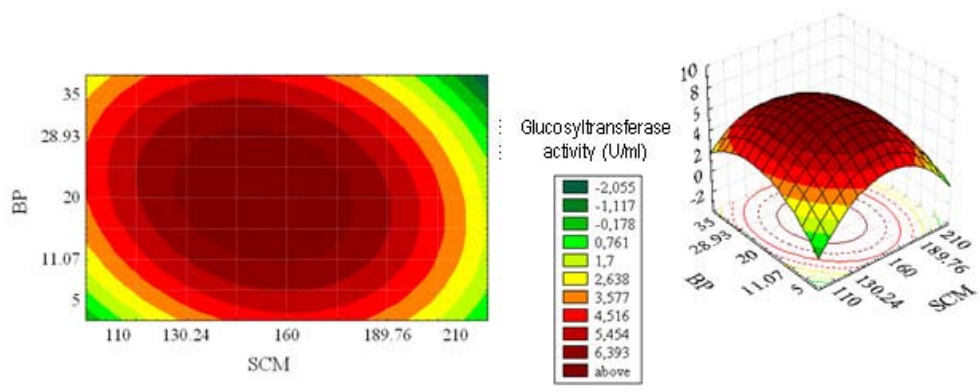

Figure 5. Contour curve and response surface for the glucosyltransferase activity as a function of sugar cane molasses (SCM) and bacteriological peptone (BP) concentrations, according to the third experimental design.
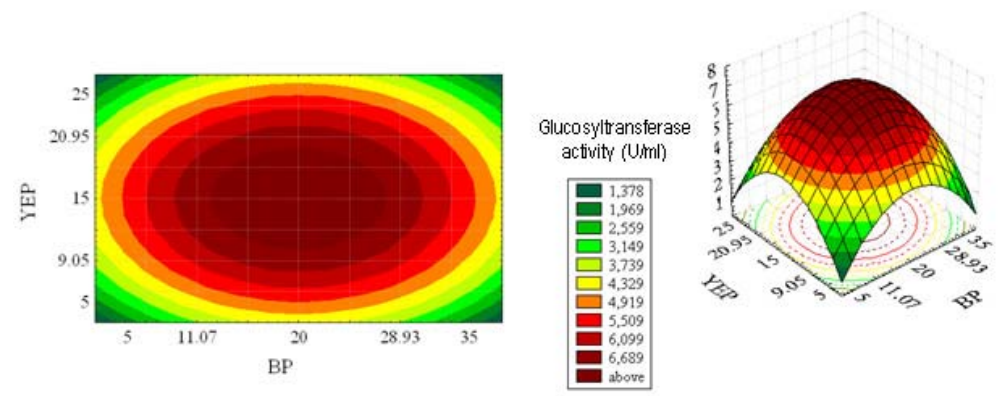

Figure 6. Contour curve and response surface for the glucosyltransferase activity as a function of bacteriological peptone (BP) and yeast extract Prodex Lac SD (YEP) concentrations, according to the third experimental design. 


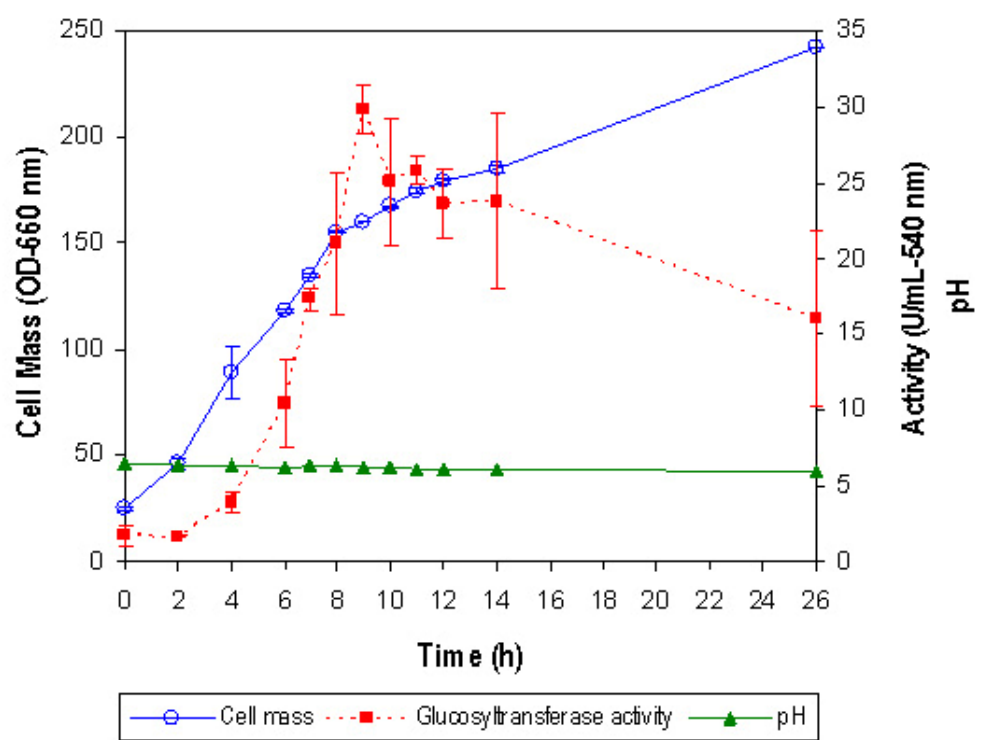

Figure 7. Time profile of fed-batch fermentation in 6.6-L fermenter using optimized medium.

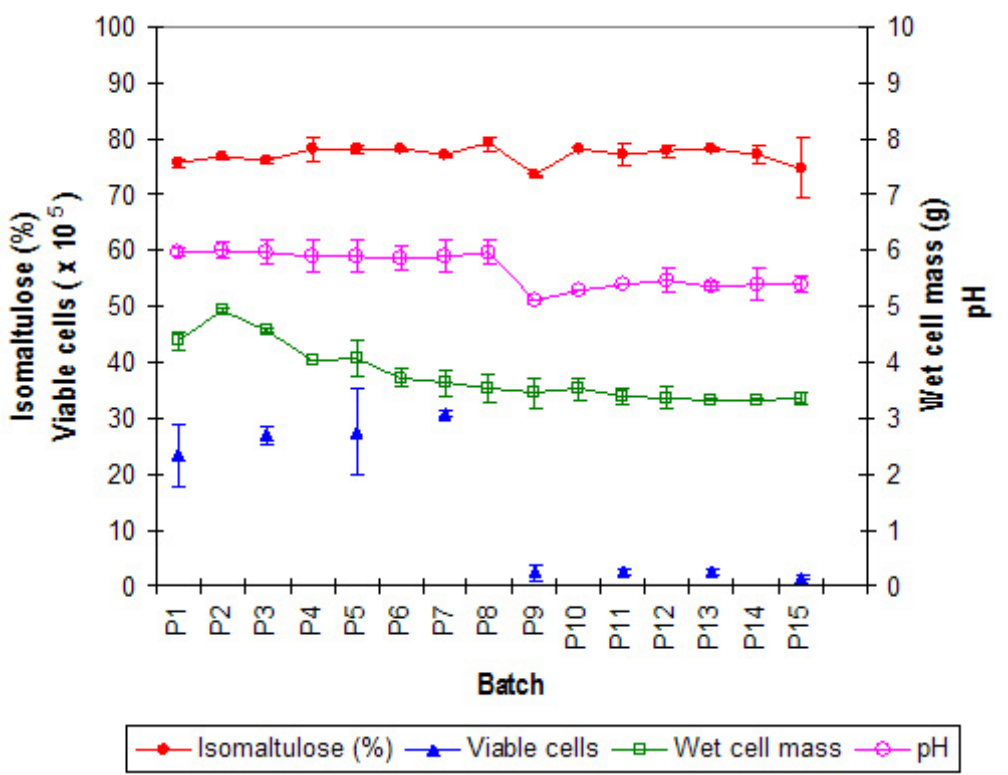

Figure 8. Repeated batch conversion of sucrose to isomaltulose using free Erwinia sp. D12 cells. 


\section{TABLES}

Table 1. Coded levels and real values (in parentheses) for the first factorial design (17 trials) and glucosyltransferase activity $(\mathrm{U} / \mathrm{mL})$.

\begin{tabular}{|c|c|c|c|c|}
\hline \multirow{2}{*}{ Assay } & \multicolumn{3}{|c|}{ Variable (g/L) } & Enzyme activity \\
& SCM $^{\mathbf{a}}$ & BP $^{\mathbf{b}}$ & YEP $^{\mathbf{c}}$ & $\mathbf{( U / m L )}$ \\
\hline 1 & $-1(130.36)$ & $-1(18.10)$ & $-1(37.14)$ & 5.63 \\
\hline 2 & $+1(219.64)$ & $-1(18.10)$ & $-1(37.14)$ & 0.13 \\
\hline 3 & $-1(130.36)$ & $+1(41.90)$ & $-1(37.14)$ & 5.97 \\
\hline 4 & $+1(219.64)$ & $+1(41.90)$ & $-1(37.14)$ & 0.20 \\
\hline 5 & $-1(130.36)$ & $-1(18.10)$ & $+1(72.86)$ & 0.63 \\
\hline 6 & $+1(219.64)$ & $-1(18.10)$ & $+1(72.86)$ & 0.28 \\
\hline 7 & $-1(130.36)$ & $+1(41.90)$ & $+1(72.86)$ & 0.32 \\
\hline 8 & $+1(219.64)$ & $+1(41.90)$ & $+1(72.86)$ & 2.12 \\
\hline 9 & $-1.68(100)$ & $0(30)$ & $0(55)$ & 2.26 \\
\hline 10 & $+1.68(250)$ & $0(30)$ & $0(55)$ & 0.38 \\
\hline 11 & $0(175)$ & $-1.68(10)$ & $0(55)$ & 0.41 \\
\hline 12 & $0(175)$ & $+1.68(50)$ & $0(55)$ & 1,19 \\
\hline 13 & $0(175)$ & $0(30)$ & $-1.68(25)$ & 0.85 \\
\hline 14 & $0(175)$ & $0(30)$ & $+1.68(85)$ & 0.40 \\
\hline 15 & $0(175)$ & $0(30)$ & $0(55)$ & 0.42 \\
\hline 16 & $0(175)$ & $0(30)$ & $0(55)$ & 0.47 \\
\hline 17 & $0(175)$ & $0(30)$ & $0(55)$ & 0.48 \\
\hline
\end{tabular}

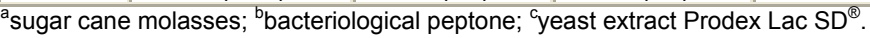

Table 2. Coded levels and real values (in parentheses) for the second factorial design (17 trials) and glucosyltransferase activity (U/mL).

\begin{tabular}{|c|c|c|c|c|}
\hline \multirow{2}{*}{ Assay } & \multicolumn{3}{|c|}{ Variable (g/L) } & Enzyme activity \\
\cline { 2 - 4 } & $\mathbf{S C M}^{\mathbf{a}}$ & $\mathbf{B P}^{\mathbf{b}}$ & YEP $^{\mathbf{c}}$ & $\mathbf{( U / m L )}$ \\
\hline 1 & $-1(120.24)$ & $-1(11.07)$ & $-1(18.10)$ & 6.34 \\
\hline 2 & $+1(179.76)$ & $-1(11.07)$ & $-1(18.10)$ & 8.28 \\
\hline 3 & $-1(120.24)$ & $+1(28.93)$ & $-1(18.10)$ & 7.56 \\
\hline 4 & $+1(179.76)$ & $+1(28.93)$ & $-1(18.10)$ & 8.97 \\
\hline 5 & $-1(120.24)$ & $-1(11.07)$ & $+1(41.90)$ & 7.39 \\
\hline 6 & $+1(179.76)$ & $-1(11.07)$ & $+1(41.90)$ & 8.68 \\
\hline 7 & $-1(120.24)$ & $+1(28.93)$ & $+1(41.90)$ & 6.63 \\
\hline 8 & $+1(179.76)$ & $+1(28.93)$ & $+1(41.90)$ & 6.28 \\
\hline 9 & $-1.68(100)$ & $0(20)$ & $0(30)$ & 4.99 \\
\hline 10 & $+1.68(200)$ & $0(20)$ & $0(30)$ & 7.01 \\
\hline 11 & $0(150)$ & $-1.68(5)$ & $0(30)$ & 7.06 \\
\hline 12 & $0(150)$ & $+1.68(35)$ & $0(30)$ & 7.47 \\
\hline 13 & $0(150)$ & $0(20)$ & $-1.68(10)$ & 8.47 \\
\hline 14 & $0(150)$ & $0(20)$ & $+1.68(50)$ & 7.06 \\
\hline 15 & $0(150)$ & $0(20)$ & $0(30)$ & 8.43 \\
\hline 16 & $0(150)$ & $0(20)$ & $0(30)$ & 8.23 \\
\hline 17 & $0(150)$ & $0(20)$ & $0(30)$ & 7.83 \\
\hline
\end{tabular}

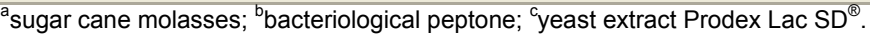


Table 3. Coded levels and real values (in parentheses) for the third factorial design (17 trials) and glucosyltransferase activity $(\mathrm{U} / \mathrm{mL})$.

\begin{tabular}{|c|c|c|c|c|}
\hline \multirow{2}{*}{ Assay } & \multicolumn{3}{|c|}{ Variable (g/L) } & Enzyme activity \\
& SCM $^{\mathbf{a}}$ & $\mathbf{B P}^{\mathbf{b}}$ & YEP $^{\mathbf{c}}$ & $\mathbf{( U / m L )}$ \\
\hline 1 & $-1(130.24)$ & $-1(11.07)$ & $-1(9.05)$ & 4.23 \\
\hline 2 & $+1(189.76)$ & $-1(11.07)$ & $-1(9.05)$ & 3.97 \\
\hline 3 & $-1(130.24)$ & $+1(28.93)$ & $-1(9.05)$ & 5.07 \\
\hline 4 & $+1(189.76)$ & $+1(28.93)$ & $-1(9.05)$ & 3.87 \\
\hline 5 & $-1(130.24)$ & $-1(11.07)$ & $+1(20.95)$ & 4.85 \\
\hline 6 & $+1(189.76)$ & $-1(11.07)$ & $+1(20.95)$ & 4.23 \\
\hline 7 & $-1(130.24)$ & $+1(28.93)$ & $+1(20.95)$ & 5.53 \\
\hline 8 & $+1(189.76)$ & $+1(28.93)$ & $+1(20.95)$ & 3.15 \\
\hline 9 & $-1.68(110)$ & $0(20)$ & $0(15)$ & 4.89 \\
\hline 10 & $+1.68(210)$ & $0(20)$ & $0(15)$ & 3.27 \\
\hline 11 & $0(160)$ & $-1.68(5)$ & $0(15)$ & 6.14 \\
\hline 12 & $0(160)$ & $+1.68(35)$ & $0(15)$ & 4.32 \\
\hline 13 & $0(160)$ & $0(20)$ & $-1.68(5)$ & 5.19 \\
\hline 14 & $0(160)$ & $0(20)$ & $+1.68(25)$ & 4.91 \\
\hline 15 & $0(160)$ & $0(20)$ & $0(15)$ & 7.47 \\
\hline 16 & $0(160)$ & $0(20)$ & $0(15)$ & 7.12 \\
\hline 17 & $0(160)$ & $0(20)$ & $0(15)$ & 7.19 \\
\hline
\end{tabular}

${ }^{a}$ sugar cane molasses; ${ }^{b}$ bacteriological peptone; ' yeast extract Prodex Lac $\mathrm{SD}^{\circledR}$.

Table 4. Main effects and interactions analysis for glucosyltransferase activity from the first and second factorial designs.

\begin{tabular}{|c|c|c|c|c|c|c|c|c|c|}
\hline \multicolumn{5}{|c|}{ First factorial design } & \multicolumn{5}{|c|}{ Second factorial design } \\
\hline Factor & Effect & Std. Err. & t-value & p-value & Factor & Effect & Std. Err. & t-value & p-value \\
\hline (1) $\mathrm{SCM}^{\mathrm{a}}(\mathrm{L})$ & -1.90 & 0.02 & -118.74 & $0.00007^{*}$ & (1)SCM (L) & 1.13 & 0.17 & 6.82 & $0.02082^{* *}$ \\
\hline $\operatorname{SCM}(Q)$ & 1.04 & 0.02 & 59.08 & $0.00029^{*}$ & $\operatorname{SCM}(\mathrm{Q})$ & -1.28 & 0.18 & -7.01 & $0.01972^{* *}$ \\
\hline$(2) \mathrm{BP}^{\mathrm{b}}(\mathrm{L})$ & 0.48 & 0,02 & 29.69 & $0.00113^{*}$ & (2)BP (L) & -0.08 & 0.17 & -0.49 & 0.67433 \\
\hline $\mathrm{BP}(\mathrm{Q})$ & 0.68 & 0.02 & 38.31 & $0.00068^{*}$ & $\mathrm{BP}(\mathrm{Q})$ & -0.38 & 0.18 & -2.08 & $0.17278^{* *}$ \\
\hline (3)YEP ${ }^{\mathrm{C}}(\mathrm{L})$ & -1.37 & 0.02 & -85.28 & $0.00014^{*}$ & (3)YEP (L) & -0.66 & 0.17 & -4.01 & $0.05682^{* *}$ \\
\hline YEP (Q) & 0.55 & 0.02 & 31.06 & $0.00104^{*}$ & YEP (Q) & -0.02 & 0.18 & -0.13 & 0.90632 \\
\hline$(1) \times(2)$ & 0.47 & 0.02 & 22.61 & $0.00195^{*}$ & $(1) \times(2)$ & -0.54 & 0.22 & -2.51 & $0.12889^{* *}$ \\
\hline (1) $\times(3)$ & 3.18 & 0.02 & 151.86 & $0.00004^{*}$ & (1) $\times(3)$ & -0.60 & 0.22 & -2.79 & $0.10795^{* *}$ \\
\hline$(2) \times(3)$ & 0.28 & 0.02 & 13.44 & $0.00549^{*}$ & $(2) \times(3)$ & -1.27 & 0.22 & -5.88 & 0.02772 \\
\hline
\end{tabular}

${ }^{a}$ sugar cane molasses; ${ }^{b}$ bacteriological peptone; ${ }^{c}$ yeast extract Prodex Lac SD ${ }^{\circledR}$

(L): linear factor

(Q): quadratic factor

*Significant factors $(p<0.05)$

${ }^{*}$ Significant factors $(p<0.20)$ 
Table 5. ANOVA for the first factorial design.

\begin{tabular}{|l|c|c|c|c|}
\hline $\begin{array}{c}\text { Source of } \\
\text { variation }\end{array}$ & Sum of square & $\begin{array}{c}\text { Degrees of } \\
\text { freedom }\end{array}$ & Mean square & F-ratio (model significance) \\
\hline Regression & 45.53 & 8 & 5.69 & $7.06^{\mathrm{a}}$ \\
\hline Residual & 6.45 & 8 & 0.81 & \\
\hline Lack of fit & 6.44 & 6 & 1.07 & \\
\hline Pure error & 0.002 & 2 & 0.001 & \\
\hline Total & 51.97 & 16 & & \\
\hline
\end{tabular}

Determination coefficient: $R^{2}=0.85 ; F_{0.95,8,8}=3.44$.

${ }^{\mathrm{a}} \mathrm{F}$-ratio (regression/residual).

Table 6. ANOVA for the second factorial design.

\begin{tabular}{|l|c|c|c|c|}
\hline $\begin{array}{c}\text { Source of } \\
\text { variation }\end{array}$ & Sum of square & $\begin{array}{c}\text { Degrees of } \\
\text { freedom }\end{array}$ & Mean square & F-ratio (model significance) \\
\hline Regression & 15.75 & 6 & 2.63 & $19.13^{\mathrm{a}}$ \\
\hline Residual & 1.37 & 10 & 0.14 & \\
\hline Lack of fit & 1.56 & 8 & 0.19 & \\
\hline Pure error & 0.19 & 2 & 0.09 & \\
\hline Total & 17.12 & 16 & & \\
\hline
\end{tabular}

Determination coefficient: $R^{2}=0.90 ; F_{0.80,6,10}=4.37$.

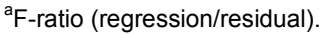

Table 7. ANOVA for the third factorial design.

\begin{tabular}{|l|c|c|c|c|}
\hline $\begin{array}{c}\text { Source of } \\
\text { variation }\end{array}$ & Sum of square & $\begin{array}{c}\text { Degrees of } \\
\text { freedom }\end{array}$ & Mean square & F-ratio (model significance) \\
\hline Regression & 24.84 & 4 & 6.21 & $28.53^{\mathrm{a}}$ \\
\hline Residual & 2.61 & 12 & 0.28 & \\
\hline Lack of fit & 2.55 & 10 & 0.25 & \\
\hline Pure error & 0.07 & 2 & 0.03 & \\
\hline Total & 27.45 & 16 & & \\
\hline
\end{tabular}

Determination coefficient: $R^{2}=0.94 ; F_{0.95,4,12}=3.26$.

${ }^{\mathrm{a}} \mathrm{F}$-ratio (regression/residual).

Table 8. Conversion performance of the free cell system during the fifteen successive conversion batches of sucrose to isomaltulose.

\begin{tabular}{|c|c|c|c|c|c|c|c|c|c|c|c|c|c|c|c|}
\hline & \multicolumn{15}{|c|}{ Batch } \\
\hline & $1^{\text {st }}$ & $2^{\text {nd }}$ & $3^{\text {rd }}$ & $4^{\text {th }}$ & $5^{\text {th }}$ & $6^{\text {th }}$ & $7^{\text {th }}$ & $8^{\text {th }}$ & $9^{\text {th }}$ & $10^{\text {th }}$ & $11^{\text {th }}$ & $12^{\text {th }}$ & $13^{\text {th }}$ & $14^{\text {th }}$ & $15^{\text {th }}$ \\
\hline Sucrose consumed (\%) & 95,1 & 97,4 & 96,9 & 98,8 & 100,0 & 100,0 & 100,0 & 98,5 & 94,6 & 100,0 & 98,1 & 99,2 & 100,0 & 98,6 & 95,5 \\
\hline Isomaltulose produced (\%) & 75,6 & 76,7 & 76,2 & 78,3 & 78,1 & 78,2 & 77,1 & 79,2 & 73,4 & 78,2 & 77,3 & 77,8 & 78,3 & 77,3 & 74,8 \\
\hline Productivity (g/L $\times \mathrm{h})^{*}$ & 1,1 & 1,1 & 1,1 & 1,1 & 1,1 & 1,1 & 1,1 & 1,1 & 1,0 & 1,1 & 1,1 & 1,1 & 1,1 & 1,1 & 1,0 \\
\hline
\end{tabular}

*Productivity (isomaltulose concentration/incubation time). 